University of Michigan Law School

University of Michigan Law School Scholarship Repository

Articles

Faculty Scholarship

1913

\title{
The Character of User in Prescription
}

\author{
Ralph W. Aigler \\ University of Michigan Law School
}

Available at: https://repository.law.umich.edu/articles/1090

Follow this and additional works at: https://repository.law.umich.edu/articles

Part of the Property Law and Real Estate Commons, and the State and Local Government Law Commons

\section{Recommended Citation}

Aigler, Ralph W. "The Character of User in Prescription." Mich. L. Rev. 11 (1913): 384-6.

This Response or Comment is brought to you for free and open access by the Faculty Scholarship at University of Michigan Law School Scholarship Repository. It has been accepted for inclusion in Articles by an authorized administrator of University of Michigan Law School Scholarship Repository. For more information, please contact mlaw.repository@umich.edu. 


\section{Michigan LaW RevieW}

PUBLISHED MONTHLX DURING THE ACADEMIC YEAR, EXCIUSIVE OF OCTOBER, BY THE LAW FACULTY OF THE UNIVERSITY OF MICHICAN

\section{EVANS HOXBROOK, Editor}

HEIRRX M. BATES
. ADVISORY BOARD.

VICTOR H. I,ANE
HORACE L. WIL,GOS

Editorial Assistants, appointed by the Faculty from the Class of 1913:

CharLes H. AVERT, of Wisconsin. PETER BALKENia, of lowa. GEORGE S. BURGESS, of Michigan. JAMrES CLEARY, of Ireland. George A. Cram, of Michigan. SIDNEY E. DOXLE. of Michigan. MORRIS FELDSTEIN, of Pentisylvania. JACE M. HENDRICK, of Colorado. WILLIAM T. FOFFMAN, of Pentisylvania. JOSEPE J. KENNEDY, of Ohio.
ROBERT I. MAYALL, of Oklahoma. Wrison W. MrLIs, of New Mexico. SAMTUEL H. MORRYS, of ATizona. BRANCIS M. MIURPEY, of Ohio. Crazence H. Royon, of Ohio. BURKE W. SHARTEL, of Oklahoma. Frederick R. Shearer, of Indiana. MAURICE SUGAR, of Michigan. Charles A. Wagner, of Michigan. HECTOR S. YOUNe, of Ohio.

\section{NOTE AND COMMENT.}

The Character of User in Prescription,-As the possession of the claimant in a case of adverse possession must be shown to have been adverse in order to ripen into title, so also must the user in prescription be shown to have been adverse during the entire prescriptive period. As to the burden of proving the adverse character of the possession in the first case there seems to be doubt whether there is a presumption of adverseness by showirg: open possession and acts of ownership, or whether there is a burden upon the claimant to go further. See 2 ANS. \& ENG. ENCY. L. \& P. 392, and cases there cited. The usual doctrine would seem to be that it is sufficient for the claimant to prove the fact of -possession together with acts of ownership, as for instance, the taking of the profits of the land. Of course in order to acquire title he must show that his possession had the further characteristics of openness, continuity, exclusiveness, etc. But, generally speaking, facts of the nature above indicated are sufficient to show the hostile or adverse character of his possession. As to the situation when the possession thas been due to a mistaken belief as to ownership see II MICH. L. REv. 57 .

The adverse character of the user in prescription causes more trouble. 
In prescription there is no taking possession of a parcel of land and exercising of those unequivocal acts of ownership as in adverse possession. The user, of course, must be proved, also that it was open, notorious, continuous, etc. The difficulty arises in determining in a given case, such user being shown, whether it was permissive or adverse. Ordinarily there is ${ }_{\llcorner}$no direct evidence showing clearly which it was, and so the question must be determined from the circumstances of the particular case. In a large number of cases it is said that open user for the statutory period is presumptively under claim of right, and therefore is adverse. Carmody v. Mulroony, $87 \mathrm{Wls}$. 552; Smith v. Pennington, I22 Ky. 355, 9I S. W. 730, 8 L. R. A. (N. S.) I49; Barnes v. Haynes, I3 Gray I88; Hammond v. Zelmer, 23 Barb. 473; Paz'y v. Vance, 56 Oh. St. 162; Garrett v. Jackson, 20 Pa. St. 33I; Fleming v. Howvard, I50 Cal. 28, 87 Pac. 908; Mitchell v. Bain, I42 Ind. 604; Cox v. Forrest, 6o Md. 74; Clement v. Bettle, 65 N. J. L. 675 ; Nicholls v. Wentzeorth, 100 N. Y. 455 ; Chalk v. McAlily, II Rich. L. I53; Arbuckle v. Ward, 29 Ut. 43 ; Rogerson $\mathrm{v}$ Shepherd, $33 \mathrm{~W}$. Va. 307 . In Indiana there seems to be a statute to that effect. On the other hand, in C.B. \& Q.R. Co. v. Ives, 202 Ill. 69 , where it appeared that the user had been open and notorious for the prescriptive period, the court said in substance that since there was no evidence to show that the user had been hostile the claimant had not made out his case. Similar to the last cited case in the respect referred to are Railroad Co. v. Johnson, 205 Ill. 598;Stewart v. Andrezes, 239 I11. I86; Piano Co. v. Forbes, I29 Ala. 471; Fish Co. v. Dudley, 37 Conn. I36. In the Ives case the very circumstances of the case negatived the hostile character of the user. In other words, the more reasonable explanation of the user was that it was by permission. The statement sometimes made (see note in 8 L. R. A. [N. S.] I49) that open user for the prescriptive period is presumptively under a claim of right, and therefore adverse, is not quite accurate. Perhaps the following is more nearly accurate: open user for the prcscriptive period is presumptively adverse unless under the circumstances of the case the more reasonable explanation of the user is that it was by permission. Or, putting it somewhat differently: open, continuous, and notorious user is presumptively adverse, but the presumption may be overcome by the very circumstances of the case showing that the reasonable explanation of the user is that it was throughout permissive. But then the presumption does not help much.

In determining whether the user is explained more reasonably on the ground of permission, or that it was because the claimant had a right, there are involved a question of fact and the exercise of judgment. It would seem to make a big difference over what part of a man's land the right is being exercised. For example, driving across waste land would, or could very reasonably be explained on the basis of permission, while a way over valuable, cultivated lands could be explained in reason, perhaps, only on the basis that the claimant had such a right, for otherwise surely the servient owner would not have sat by quietly. See Fish Co. v. Dudley, 37 Conn. 136, also Piano Co. v. Forbes, I29 Ala. 47I. In the very late case of Bruner Granitoid Co. v. Lime \& Cennent Co. (Mo. App.) 152 S. W. 6or, it was held 
that a long continued open user of a switch track by the defendant was more reasonably explained on the ground of permission because the plaintiff, across whose lands the switch track in part was located, had during the same time also been using the track. See also Barber v. Bailey, (Vt.) 84 At1. 608 .

R. W. A.

) 